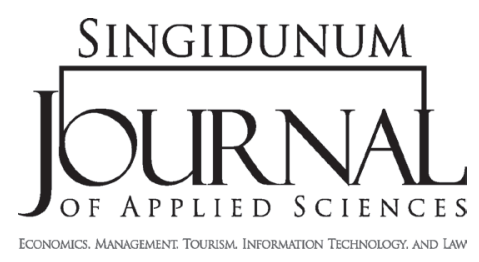

\section{INTEGRATING SUSTAINABLE TOURISM IN TOUR OPERATORS' SUPPLY CHAIN}

\author{
Vesna Spasić \\ Singidunum University, Department for Tourism and Hospitality Management, \\ 32 Danijelova Street, Belgrade, Serbia
}

\begin{abstract}
:
Implementation of the concept of sustainable tourism development in the business of tour operators is based on the respect of environmental, social and economic aspects in all stages of the formation and execution of travel arrangements. For tour operators, the integration of these principles in the process of creating a supply chain and contracting services with providers is of particular importance. In this way, the tour operator can achieve a greater level of control over inputs included in a travel arrangement, guaranteeing the quality of customer services and taking responsibility in relation to other stakeholders. Experiences of tour operators in leading source markets have shown that it has long-term positive economic effects. Although tour operators face a number of difficulties in the process of integrating sustainable tourism in the supply chain, positive experience has shown that well-placed management system and intensive long-term cooperation with providers gives good results.
\end{abstract}

SINGIDUNUM JOURNAL 2012, 9 (1): 60-66

ISSN 2217-8090

UDK 338.484:502.131.1; 338.486.23/.3

Review paper/Pregledni naučni rad

\section{Key words:}

tour operators, sustainable tourism, supply chain.

\section{INTRODUCTION}

The rapid development of tourism from the second half of the $20^{\text {th }}$ century until today, has been a significant generator of the overall economic development in many countries (Unković, 2009), but negative effects have also been reported. It is a series of negative consequences for the natural and social environment which are the result of numerous participants' actions in the tourism market, but one cannot deny that travel organizers, who have influenced the direction of massive tourist flows, have had a significant share of responsibility (Oppermann and Chon, 1997; Laws, 1997). The research conducted on the British market (Holden and Kealy, 1996; Curtin and Busby, 1999) showed that, despite the differences between mass-market tour operators and specialist tour operators, the resource destruc- tion could be the result of organized trips in both cases. It is particularly pointed out that the expected positive economic effects on a local economy and population are often missing, and representatives of tour operators point out that this is a consequence of the constraints imposed by the European Union Directive of 1992 (EC Directive on Package Travel) and responsibilities in ensuring the standard quality of services. The negative consequences of the development of mass tourism in certain areas, and particularly environmental problems which destinations in different parts of the world face, have influenced changes in strategies of tour operators in the last ten years or so. There is no doubt that the changes in business orientation of tour operators are the result of a new relation that tourists have with the natural and social environment and the development of environmental awareness of participants of tourist trips. 
This resulted in a series of joint and individual activities, and in 2000, a special initiative was adopted (Tour Operators Initiative and The Center of Enviromental Leadership in Business, 2003) in the adoption of which big international tour operators, with the support of leading international organizations (UN, UNESCO and WTO), participated. According to Holloway (2002), the most important goals of this initiative are related to the exchange of positive experience in the field of environmental problems solving, using energetic and other resources more efficiently, creating arrangements which will have a smaller impact on the natural and social environments.

\section{ECONOMIC EFFECTS OF THE INTEGRATION OF SUSTAINABLE TOURISM DEVELOPMENT IN THE BUSINESS OF TOUR OPERATORS}

Implementation of the concept of sustainable development in the business of tour operators is not only the result of changes in consumer demands and the pressure of the public, but there is a direct economic interest of travel organizers themselves. Direct short-term economic effects are visible in the savings achieved due to a more efficient use of resources, reduced energy consumption, water consumption, savings due to waste reduction and the like. Especially important are improving the quality of services and new experiences offered to consumers, which lead to a higher level of satisfaction of tourist trip participants and a larger number of repeat purchases. Creation of such an additional value and recognizable brand qualities of tour operators affect the strengthening of the market position and the increase in demand due to attracting new groups of consumers, mainly tourists who have a developed ecological awareness. Increasing the level of consumer loyalty and attracting new market segments indicate a long-term positive economic effects based on new promotional and overall marketing opportunities present in the market. A tour operator effects a higher level of trust, loyalty and motivation of employees themselves. The positive results include the establishment of better and long-term relations in cooperation with all business partners at the destinations. This reduces the risk of possible conflicts and problems in cooperation not only with direct suppliers, but also with local authorities, representatives of local communities and local population. A good reputation that a tour operator has at a destination can ensure them an easier access to certain resources, which are sometimes limited, and the sources of funding may be available for them under favourable conditions. (Integrating into Good Practices A Tour Operator's Supply Chain, 2011).

The essence of implementation of the concept of sustainable tourism development in the business of tour operators is based on taking into account the environmental, social and economic aspects in all stages of the formation and execution of travel arrangements. According to a study prepared by an association of tour operators Tour Operators' Initiative and the Center of Environmental Leadership in Business (2003), the most important areas of implementation of these principles are:

- In the product development process, where the key issue in creating package deals is the selection of integral components with minimal adverse effects on natural and social environment and ensuring long-term positive economic effects for all participants;

- In the process of procurement and contracting with suppliers, with the use of criteria based on the sustainable tourism development as the basic principle;

- In relations with customers, guaranteeing the quality integral components of an arrangement, as well as safety and security of consumers, providing the necessary information and advice for a responsible behaviour of tourists at destinations;

- In relations with destinations, by supporting the efforts of numerous participants aimed at sustainable development, particularly contributing to the realization of activities in the field of conservation and similar projects at destinations;

- In the internal management of human resources and business processes in the organizational structure of the travel organizer itself.

\section{DIFFICULTIES FACED BY TOUR OPERATORS IN THE IMPLEMENTATION OF THE CONCEPT OF SUSTAINABLE DEVELOPMENT IN ESTABLISHING} THE SUPPLY CHAIN

Achieving expected effects in the business of tour operators encounters, however, a number of limitations. They are primarily a result of the fact that tour operators do not control the largest num- 
ber of services and products involved, and tourism value chain, and they influence the overall customer satisfaction. Even when it comes to components which are an integral part of the package deal itself, a tour operator is faced with difficulties in trying to provide the required level of service quality and the implementation of sustainable development principles. Travel organizers generally do not own transport and accommodation facilities, but they provide them by contracting with suppliers. However, even though tour operators do not have direct control over the package deal components, the guarantee of quality is very important for consumers and tour operators must take responsibility to ensure the application of sustainability principles in all inputs included in their own products. It imposes tour operators the need for close cooperation with suppliers - providers of services in all stages of design and execution of an itinerary, whereby the process of procurement and contracting of constituent components of package deals is particularly significant (Jovanović, 2009).

Tour operators that have their own facilities or long-term contractual arrangements, which allows them to exercise control over services provided in accommodation facilities or provided by incoming agencies at a destination, are in a better position.

Environmental labelling of products (Eco-labels) is a useful tool that can be used by tour operators in the selection of products and services necessary for the formation of travel arrangements. These are certificates issued by specialized organizations based on specially defined environmental standards. According to the information of the World Tourism Organization there are over 100 certificates for eco-labelling in the world. Among these standards there may be differences among individual regions, but the process of finding appropriate vendors can be significantly eased for tour operators.

The extent to what a travel organizer will be in a position to adequately resolve the difficulties in trying to incorporate the principles of sustainable tourism development in the contracts it signs with suppliers, and/or with its partners in the supply chain, depends on:

- The scope and quality of available offer at a destination,

- The level achieved in the implementation of the concept of sustainable tourism development with the suppliers themselves at the destination and their willingness to balance their business with the requirements of tour operators,

- External factors which may represent key constraints to sustainable destination development (e.g. the development of a system for waste water and solid waste treatment, the policy of protection of cultural and historical heritage and natural environment and similar factors).

When planning the necessary activities, travel organizers should bear in mind that the conditions for application of the principles of sustainable tourism development differ considerably when source markets and possibilities of receiving countries, typical at a lower level of overall economic development, are compared. In these cases, tour operators require far more intensive cooperation with suppliers, also including visits to the destination, and the very process of contracting, which requires a high level of precision in defining the overall quality of services, is particularly sensitive. At tourist destinations, it is often necessary to direct the tour operator's activity towards the public sector as well in order to ensure the development of appropriate infrastructure (the system of waste recycling, wastewater treatment, development of public transport on the principles of sustainable development) (Sekulović and Unković, 2010).

It is necessary that tour operators create a policy of sustainable supply chain and an appropriate management system which includes an action plan, the basic evaluation of suppliers' services, including the perceived disadvantages and advantages, as well as the monitoring and reporting system which will ensure prompt definition of problems, as well as monitoring the progress made. The created policy must also contain motivating instruments aimed at suppliers in order to achieve the sustainable development related objectives.

\section{ESTABLISHMENT OF THE SPECIAL MANAGEMENT SYSTEM WITH THE APPLICATION OF THE CONCEPT OF SUSTAINABLE TOURISM DEVELOPMENT IN THE SUPPLY CHAIN OF TOUR OPERATORS}

For the realization of desired goals related to sustainable tourism development in a destination, a tour operator needs to set up its own management system, to adopt a special action plan, to introduce special training programs, and also to maintain a system 
of monitoring and control in order to monitor the effects achieved. Setting up a separate management system in the process of contracting with suppliers of certain services is aimed at achieving economic, environmental and social sustainability as an essential characteristic of services at a destination. For the realization of these objectives it is necessary to form teams to design and implement a certain policy (Tour Operators' Initiative and The Center of Environmental Leadership in Business, 2003).

Nowadays, it is typical for big travel organizers to form a specific organizational structure which should contribute to a more efficient application of the concept of sustainable tourism development in the process of making contracts. Practice has shown that better results can be achieved by involving representatives of various departments (department managers and representatives for individual destination, managers from the sector of contracting and procurement, human resources, marketing, production of package deals, as well as managers of the sector for quality, health and safety of consumers), and also representatives of major suppliers, who thus effect the common policy and operational activities together. The creation of a separate organizational unit for sustainable development has also produced good results. The task of this organizational unit is reduced to coordination and a series of operational activities in the implementation of adopted plans, consulting role, as well as providing technical support in all matters related to sustainable development. The organizational unit for education and training of employees is tasked with creation and implementation of training programs for employees who work on the creation and realization of a trip, and sometimes the training includes representatives of the supplier as well. The given organizational structure is characteristic of major travel organizers, and the solutions typical for medium and small businesses are in accordance with their size and specificities in the arrangement production.

In addition to defining the organizational structure, for achieving desired goals an action plan needs to be adopted. The assumption of its successful implementation is setting certain standards which specify the criteria to be used in the selection of bidders at the destination. Standards must be flexibly set so that they can be applied in different socio-economic and environmental conditions and adapt to the suppliers of various sizes and production capabilities. In this case, positive effects occur with the inclusion of supplier representatives since this may contribute to a better understanding of local conditions and help to anticipate potential problems and more effective work in finding a solution.

The process of contracting is a particularly sensitive stage. Contracting capacity utilization and different services at a destination includes the definition of product quality, price, amount of fees, implementation requirements, etc., and it is important that contracts are in a written form in order to avoid possible misunderstandings that can lead to conflicts. The criteria related to sustainability (especially minimum standards) should be incorporated in contracts with suppliers and it is essential that such issues are clearly formulated and presented to suppliers from the outset. For tour operators, it is necessary to define minimum standards that suppliers must meet, and organizers often set optional criteria, defining even the stimulus system for suppliers who want to meet those criteria.

Permanent and quality information of managers and employees, with certain training programs, is extremely important, because the representatives who work on contracting capacities and execution of package deals at the destination must be trained for active collaboration with suppliers and monitoring during the realization of activities under the action plan in the domain of sustainable development. At major tour operators, the representatives, who are in charge of the health care control and safety of tourists in hotels, often have the obligation of monitoring in terms of sustainability. To achieve this, they must go through certain training programs, and receive the precise technical instructions. Training progra$\mathrm{ms}$ and practical training also include employees of business partners at the destination. Thus, for example, training programs in hotels include employees at various levels - from managers of different sectors to the hostesses and guides.

Establishment and implementation of a monitoring system is one of the key steps in the realization of the business of tour operators on the principles of sustainable development, together with informing all participants within an organizational structure of a tour operator on the results achieved in the supply chain. It is very important that this process also includes other key stakeholders such as suppliers and other interested representatives of destinations, consumers, media representatives and others. 
In these processes, tour operators have a number of opportunities to get the role of carriers of knowledge transfers, and/or positive experiences and good practices to their business partners at the destination. Such a role of tour operators is based on the fact that they have a direct insight into changes in consumer requirements, but also that they have greater opportunities to access modern technological solutions in relation to small businesses, their business partners around the world. Activities aimed at suppliers can be related to raising awareness about the necessity of implementation of the concept of sustainable development, providing technical support and initiatives in the field of implementation of the concept of sustainable tourism development. A good example of technical support is making the manual "A Practical Guide to Good Practice: Managing Environmental and Social Issues in the Accommodations Sector" which the associations Tour Operators' Initiative and Conservation International have prepared. The manual was translated into four languages (Spanish, French, Turkish and Portuguese) and it was available in the electronic form, and 30,000 copies have been distributed through tour operators - members of this association to hotels with which they make contracts of capacities (Integrating Good Practices into A Tour Operator's Supply Chain. TO Initiative, 2011).

\section{EXAMPLES OF GOOD PRACTICE IN FORMATION AGENTS SUPPLY CHAIN}

The world's major tour operators can also be considered leaders, in a certain way, in the implementation of the concept of sustainable tourism development in the formation and realization of activities within a supply chain. For example, German LTU Touristik tour operator introduces a special technical manual that aims to help hotels in an effort to ensure ecological characteristics of their services (drinking water, the area around the hotel, saving energy, a way of buying services, waste disposal and communications). A British tour operator My Travel Northern Europe has developed a system of training programs, and it issues a special guide for hotels (50 Steps Towards a Better Environment Programme).

The world's largest tour operator - TUI particularly stands out with series of activities aiming at implementation of the concept of sustainable tourism development. The long-term strategy of devel- opment of various programs of the tour operator has a common goal: the creation of specific tourism experience creating trips that minimize negative environmental impacts, respect a specific culture and people at destinations, while providing real economic benefits for the local community (TUI Travel PLC, 2010).

In operational business TUI puts strong pressure on its business partners, primarily hoteliers, but also the carriers and other entities at a destination whose activities effect the environmental changes. It is about certain requirements based on the principles of sustainable tourism development, whereby the tour operator expresses willingness to leave the destinations which are not able to adequately solve the problems concerning the protection of natural and social environment. Within these activities, a special place belongs to the creation of a supply chain, with numerous examples of good practice around the world. To illustrate this, we will present a long-term successful business cooperation which was developed by TUI Nordic, a leading tour operator within the TUI, with the hotel group of Blue Village hotels. These are hotels, resorts and similar accommodation facilities in attractive maritime destinations, intended for clients with high requests. In the process of contracting with these accommodation facilities, the tour operator puts forth the quality which also includes environmental characteristics of products and services. The condition for establishing cooperation is the implementation of rules of conduct in the business of accommodation facilities adopted by international organizations (Code of Conduct for the Travel and Tourism Industry - World Wide Fund for Nature's). Each hotel is supposed to have a management system based on ecological principles, a special action plan on environmental protection and a responsible person that deals with issues, such as the use of products which do not pollute the environment, the procurement process in which the hotel gives priority to local manufacturers, and solid waste and used water treatment, the application of the system for saving water and energy. To achieve common results, an important part of activities refers to permanent trainings for hotel managers and regular reports which hotel managers are obliged to send to the tour operator. This has led to the expected results and today 15 TUI Nordic Blue Village hotels and resorts in Europe and Turkey have an ISO 14001 certificate (TUI Nordic, 2011). 
But, no less significant are other specific initiatives TUI Travel PLC. With the aim of establishing more quality relationships with all parties interested in the implementation of the concept of sustainable tourism development, TUI introduced a special interactive environmental website in 2001 . The website is designed for the destination partners, representatives of state and civil organizations at destinations, organizations dealing with conservation or other issues related to environment protection, travel agencies, consumers and media representatives. The website provides not only information, but, which is especially important, it provides an opportunity for communication and dialogue. Significant effects in the sales activities are provided thanks to updated information also intended to arrangements vendors as well who can establish a dialogue with potential customers in a proper way. It is particularly important to provide a complete insight into the TUI activities for the environmental protection as a part of the overall quality of products and its ethical principles by which it seeks to differentiate itself from the competition.

TUI devotes special attention to organizing trips to sensitive regions, such as travel programs in areas with dolphins or diving in protected areas with coral reefs. One of the recent activities related to the development of a specific manual intended for tourists (Little Guide for Protecting Species in cooperation with the German Federal Agency for Nature Conservation). The manual is aimed to inform tourists and provide a practical help with buying souvenirs, also trying to prevent any unpleasant situations tourists could face due to illegal purchase. The manual actually contains lists of illegal souvenirs made of protected plant and animal species in some areas, as well as desirable souvenirs with the purchase of which tourists influence the sustainable growth of a local economy. (TUI Group - Sustainable Development, 2011).

However, one should also point to positive experiences of less known tour operators. Atlas Voyages (Suppliers' Hygiene Control Campaign, 2011) is a leader in tour operator business in the market of Morocco. A new approach to contracting services with providers in the area of Morocco has been applied since 2004, placing special requests regarding food quality and hygiene. The tour operator's management has identified 17 hotels and restaurants as the most important suppliers, starting from the amount of contracted and provided services, and it has directed the program of activities on quality control to them. A specialized London agency dealing with the HACCP standard implementation was also involved in the process, so that all 17 suppliers have fully achieved the needed results applying the standards which have guaranteed food quality. In the next stage, the cooperation with suppliers was related to energy conservation and recycling of waste materials. In the process of cooperation with suppliers, a significant role features the set monitoring system based on regular visits to facilities and monthly reports submitted to the tour operator's management. In the process of evaluation of the achieved results, an important role also features tourists who, through a detailed questionnaire, assess the quality of services. Activities of this tour operator have contributed to the increasing level of service quality in hotels and restaurants, which is especially important for a country where hygiene and food quality are one of the limits in tourism development that need to be overcome in approaching the international market. There is also a general opinion that Atlas Voyages has positively influenced the adoption of national legislation covering issues of hygiene and food quality in hospitality facilities. (Atlas Voyages. Suppliers' Hygiene Control Campaign, 2011).

\section{CONCLUSION}

The criteria applied by tour operators in the choice of destinations and services, which they will include in their travel programs, today inevitably include the evaluation of the implementation of the concept of sustainable tourism development. This assessment, however, is not applied for tour operators in our country. Most of them puts price to the fore as an instrument for achieving competitive advantage as a result of the limited purchasing power and underdeveloped environmental awareness.

However, entering the international market imposes the need that our incoming tour operators offer products with characteristics of sustainable development. The prerequisite for this is an innovated approach in cooperation with domestic suppliers (hoteliers, transport companies, service providers in rural tourism, etc.) where it is necessary to note that tour operators are faced with a number of limiting factors. In Serbia, very serious environmental problems are present in a large number of tourist destinations, but the fact is that even the highest category of hotels still do not show readiness to respond to the demands of the leading European source markets (with few exceptions such as a small 
number of hotels in Belgrade or individual farms in Vojvodina). Although there are no hotels in Serbia which have an eco-label of green hotels, new initiatives primarily related to Belgrade hotels provide some encouragement. The Hyatt Regency is the first hotel that has formed the so-called green team, and its activities are primarily focused on cost-effective heating system, light control, recycling of waste materials. In Serbia, 54 new hotels have been built in the last 3 years and most of them use new environmental technologies, so it should be expected that more opportunities for the offer of tourism products with the characteristics of sustainable development will be created.

\section{REFERENCES}

Atlas Voyages. Suppliers' Hygiene Control Campaign [online]. Available from: http://www.toinitiative.org/ fileadmin/docs/case_studies/atlas_sc.pdf [accessed: 1 September 2011].

Curtin, S., Busby, G. (1999) Sustainable destination development: The Tour Operators Perspective, International Journal of Tourism Research. 1 (2), 135-147. [online] Available from: http://plymouth.academia. edu/GrahamBusby/Papers/10092/Sustainable_Destination_Development_the_tour_operator_perspective [accessed: 10 September 2011].

Holden, A., Kealy, H. (1996) A Profile of UK Outbound Environmentally Friendly Tour Operators. Tourism Management. 1 (96), 60-64.

Holloway, J.C. (2002) The Business of Tourism. $6^{\text {th }}$ ed. London: Pitman Publishing.
Integrating Good Practices into A Tour Opperator's Supply Chain. TO Initiative. [online]. Available from: www. toinitiative.org/index.php?id=53 [accessed: 15 February 2011].

Jovanović, V. (2009) GIS orijentisane turističke prostorno-vremenske analize kao podrška održivom razvoju. Singidunum revija. 6 (1), 122-131. (in Serbian)

Laws, E. (1997) Managing Packaged Tourism. London: International Thomson Business Press.

Oppermann, M., Chon, K.S. (1997) Tourism in Developing Countries. London: Thomson Business Center.

Sekulović, N., Unković, S. (2010) Mere za ublažavanje negativnog dejstva svetske ekonomske krize na turizam. Singidunum revija. 6 (2), 181-192. (in Serbian)

Tour Operators Initiative and The Center of Enviromental Leadership in Business (2003). Supply chain management for tour operators [online]. Available from: (http://www.conservation.org/Documents/CI_ ecotourism_supply_chain_mgt_handbook_nov2003. pdf) [accessed: 17 March 2011].

TUI Group - Sustainable Development. [online]. Available from: http://www.tui-group.com/en/sustainability/ [accessed: 19 January 2011].

TUI Nordic. Promoting Codes for Conduct for Responsible Tourism Among Suppliers [online]. Available from: http://www.toinitiative.org/fileadmin/docs/case_studies/tui_sc.pdf [accessed: 19 January 2011].

TUI Travel PLC. Sustainable Travel Report 2010. [online]. Available from: http://www.sd2010.tuitravelplc. com [accessed: 2 September 2011].

Unković, S. (2009) Međunarodni turizam u uslovima ekonomske krize sa posebnim osvrtom na Jugoističnu Evropu. Singidunum revija. 6 (1), 112-121. (in Serbian)

\section{PRIMENA KONCEPCIJE ODRŽIVOG RAZVOJA TURIZMA U LANCU SNABDEVANJA TUROPERATORA}

\section{Rezime:}

Primena koncepcije održivog razvoja turizma u poslovanju turoperatora zasniva se na uvažavanju ekoloških, socijalnih i ekonomskih aspekata u svim fazama procesa formiranja i izvođenja turističkih aranžmana. Za turoperatore poseban značaj ima integrisanje ovih principa pri formiranju lanca snabdevanja i ugovaranju usluga sa dobavljačima. Na taj način turoperator može da ostvari veći stepen kontrole nad inputima koje uključuje u turistički aranžman garantujući kvalitet usluga potrošačima i preuzimajući odgovornost u odnosu na druge stakeholdere. Iskustva turoperatora na vodećim emitivnim tržištima pokazala su da to ima dugoročne pozitivne ekonomske efekte. Iako su u procesima implementiranja principa održivosti u lanac snabdevanja turoperatori suočeni sa nizom teškoća, pozitivna iskustva su pokazala da dobro postavljen menadžment sistem i intenzivna dugoročna saradnja sa dobavljačima daju dobre rezultate.

\section{Ključne reči:}

turoperatori, održivi turizam, lanac snabdevanja.

Received: October 12th, 2011 Correction: November 21st, 2011

Accepted: December 2nd, 2011 